\title{
GALANG POTENSI MEMERANGI TEROR
}

\section{Oleh: Shohibul Anshor Siregar}

\section{I.LATAR BELAKANG}

Setelah kejadian 911 arah yang begitu jelas memusuhi Islam begitu kuat. Cukup populer pemahaman saat ini di seluruh dunia bahwa "tidak semua muslim teroris, tetapi semua teroris adalah muslim”.

Statemen itu adalah bagian dari bahasa dan publikasi dunia yang secara hegemonik menentukan degradasi komunitas dan Negara muslim yang diposisikan secara peyoratif.

Pada abad XIX susah mendapatkan data yang mengaitkan komunitas muslim dengan tindakan teroris. Pada tahun 1881 Tsar Alexander II dicederai dalam sebuah peledakan bom yang menewaskan 21 orang. Belakangan diketahui bahwa pelakunya adalah Ignacy Hryniewiecki, bukan seorang muslim. Pada tahun 1886, saat konflik perburuhan, sebuah bom meledak di Haymarket Square, Chicago menewaskan 20 orang.

\section{Bagaimana pada abad XX?}

- Tanggal 6 September 1901 Presiden AS William McKinley menjadi korban pembunuhan pada Pameran Pan-Amerika di Buffalo, New York. Seorang anarkis (28 tahun), Leon Czolgosz, adalah pelakunya. la, bukan seorang muslim.

- Tanggal 1 Oktober 1910 ledakan bom di gedung surat kabar Time, Los Angeles membunuh 21 orang. Pelakunya dua orang beragama Kristen, James dan Joseph.

- Tanggal 28 Juni 1914 Archduke of Austria dan isterinya tewas dalam pembunuhan di ibukota provinsi Austro-Hungaria dari Bosnia dan Herzegovina, oleh Gavrilo Princip, berusia 19 tahun. Anak muda ini adalah anggota Young Bosnia, bukan seorang muslim.

- Tanggal 19 April 1925 terjadi ledakan bom di gereja St.Negelya, Sofia, ibukota Bulgaria., yang menewaskan ratusan orang. Pelakunya ialah partai komunis dan tak satu pun di antara pelakunya beragama Islam.

- Tanggal 9 Oktober 1934 King Alexander I Yugoslavia terbunuh dengan sebuah tembakan oleh Vlada Georgieff, bukan seorang muslim.

- Pada tanggal 1 Mei 1961 pesawat milik Amerika Serikat. Pelakunya ialah Ramirez Ortiz, bukan muslim. Seorang non muslim pada tanggal 28 Agustus 1968 juga tercatat membunuh Duta Besar Amerika Serikat untuk Guatemala. Pada tanggal 30 Juli 1969 Duta besar Amerika Srikat untuk Jepang juga terbunuh dengan bersenjatakan sebilah pisau, oleh seorang berkewarganegaraan Jepang, non muslim. Tanggal 3 September 1969, Duta Besar Amerika Serikat untuk Brazil diculik. Bukan oleh seorang muslim.

- Tanggal 19 April 1995 Gedung Federal di Oklahoma dibom dengan menggunakan sebuah truk yang menyebabkan tewasnya ratusan orang. Pelakunya Timothy dan Terry, anggota gerakan sayap kanan. Bukan muslim. 


\section{Rentang waktu antara 1941 hingga 1948 usai perang dunia II, 259 kali serangan teroris}

dilakukan oleh teroris Jahudi.

- Pada tanggal 22 Juli 1946 bom yang diledakkan di Hotel King David di Jerusalem dilakukan oleh geng teroris bernama Irgun bekerja sama dengan geng Stern yang dikenal memiliki hubungan

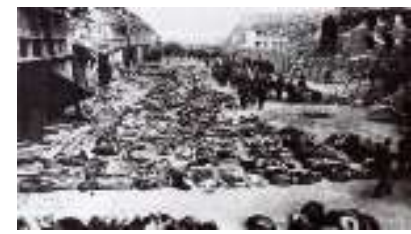
manajemen khusus di bawah arahan Managem Begin, dengan korban 91 orang termasuk tokoh Desir Yassin. Dikhabarkan bahwa mantan Perdana Menteri Shamir juga pernah menjadi anggota Irgun dan kemudian pindah ke Stern yang dikenal memang lebih radikal. Tetapi bom itu diasosiasikan dengan pekerjaan muslim. Dua tahun kemudian, dia menjadi Perdana Menteri Israel. la juga kemudian menjadi penerima hadiah Nobel perdamaian. Bayangkanlah itu. Sebelum 1945 Israil tidak akan ditemukan dalam peta. Para teroris itulah yang membangunnya.

- Di Jerman antara tahun 1968 sampai 1992, geng bernama Baader Meinhoff membunuh sejumlah orang tak berdosa.

- Brigade Merah di Italia melakukan pembunuhan-pembunuhan atas sejumlah orang tak berdosa, juga menculik dan setelah 5 hari kemudian membunuh Aldo Moro, mantan perdana menteri Italia.

- Tanggal 20 Maret 1995 Aum Shinrikyo, sebuah sekte Budha dari Jepang, menimbulkan kehebohan berskala internasional, ketika beberapa anggotanya melaksanakan serangan gas sarin di kereta bawah tanah Tokyo. Teror ini menewaskan 12 orang, 54 orang sakit parah, serta memengaruhi lebih dari 980 orang.

- Di Inggeris tentara separatis Irish Republican Army (IRA) selama ratusan tahun melakukan kekerasan-kekerasan dengan korban yang besar. Mereka beragama Katholik dengan perjuangan yang ideologis. Tahun 1991 IRA juga membom kantor BBC.

- Di Spanyol dan Perancis, Euskadi Ta Askatasuna (ETA), sebuah kelompok gerakan separatis bersenjata tercatat melakukan ratusan kali terror dengan jumlah korban yang juga begitu besar, sejak tahun 1961 hingga 2011.

- The Lord's Resistance Army (LRA), yang juga dikenal dengan nama Lord's Resistance Movement, adalah sebuah kelompok pemberontak sekte heterodox Christian yang beroperasi di Uganda bagian Utara, Sudan Selatan dan Republik Afrika Tengah dan Republik Demokratik Kongo. Mereka melatih anak-anak untuk melakukan teror. Tetapi begitulah dunia tidak menyebutnya sebagai apa adanya.

- Di Sri Langka ada Liberation Tigers of Tamil Eelam (LTTE) atau yang di Indonesia lebih dikenal dengan nama Macan Tamil. la adalah suatu gerakan insurgensi yang berbasiskan etnis, bertujuan mendirikan Negara Tamil yang independen di Tenggara Sri Lanka.

- Sejak dibentuk pada tahun 1976 oleh Velupillai Prabhakharan telah melancarkan gerakan-gerakan

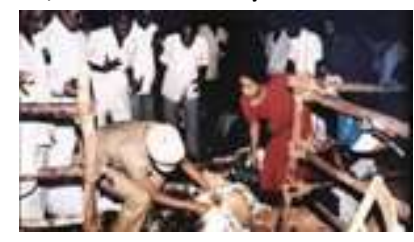
gerilya melawan pemerintah Sri Lanka. Gerakan teror ini lebih terkenal karena divisi bom bunuh dirinya bernama Macan Hitam yang dibentuk pada tahun 1987 dan telah melancarkan ratusan aksi bom bunuh diri (termasukpembunuhan Perdana Menteri India, Rajiv Gandhi). Mereka Hindu.

- Di India boleh dikatakan hampir semua kelompok agama termasuk kelompok komunis memiliki organisasi teroris dengan catatan-catatan kekerasan menewaskan banyak nyawa tak berdosa. Media tak tertarik menelisiknya sebagai teror berdasarka ideologi dan agama. Ketika muncul sebagai newsbrief di halaman media, sangat berbeda jika ada kejadian kekerasan ketika di manamana dikaitkan dengan muslim.

Siapakah manusia paling bengis di dunia sepanjang sejarah yang pernah membunuh banyak orang? 
- Sebutlah Hitler yang membunuh 6 juta Jahudi. Itu belum termasuk korban pada perang dunia kedua lainnya. Siapa dia? Dia orang Kristen.

- Joseph Stalin adalah salah satu dari tujuh anggota pertama Politbiro, yang didirikan pada tahun 1917 untuk mengelola Revolusi Bolshevik, bersama Lenin, Zinoviev, Kamenev, Trotsky, Sokolnikov dan Bubnov. Tokoh besar komunis ini menewaskan antara 20 sampai 60 juta jiwa dalam sejarah Rusia.

- Di China, Mao Tse Tung tercatat menewaskan paling sedikit 14 juta jiwa. la non muslim.

- Benito Musollini menewaskan 400 ribu jiwa. la bukan muslim. Selama revolusi Francis Maximilin Robespierre bertanggung jawab atas tewasnya 200.000 jiwa.

- Ashoka dalam salah satu pertempuran Kalingga tercatat membunuh 100.000 jiwa. Dia orang Hindu.

- Saddam Husein menewaskan 100.000 ribu jiwa, namun itu semua harus dikaitkan dengan embargo Barat dan Geroge Bush yang membunuh lebih dari setengah juta anak-anak di Irak.

- Banyak orang mengklaim tewasnya 500.000 orang era Soeharto, tetapi ini tak mungkin dibandingkan dengan Stalin, Hitler dan Mao. Soeharto bukan muslim fundamentalis, ekstrimis atau teroris . Itu tak mungkit dikaitkan dengan Islam.

MC Bassiouni (Emeritus Professor of Law dari DePaul University 1964-2012) menegaskan bahwa untuk mendefinisikan terorisme yang tak ambigu dan memuaskan setiap orang, adalah sebuah ketak-mungkinan. Hal itu disebabkan oleh perbedaan fundamental values yang berbenturan antara satu dan lain orang, antara satu dan lain bangsa, dan antara satu agama dengan lain dalam menilai tindakan kekerasan itu.

Bahwa semua yang disebut terorisme itu adalah perang non-official dan jika dibandingkan dengan banyak perang yang tercatat dalam sejarah, sangat tidak

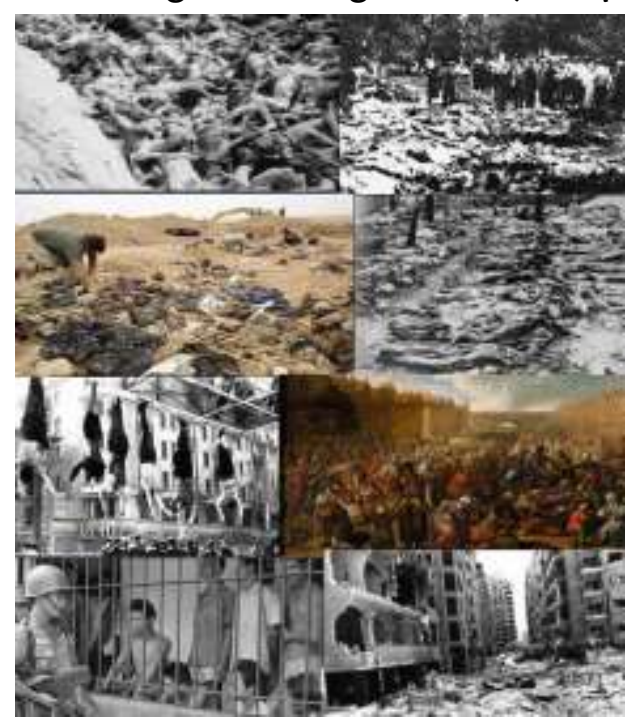

gosple, glory dan gold. bermakna baik dilihat dari aspek korban maupun akibatnya bagi kehidupan manusia. Memang agak sinis, tetapi Professor Johnson (Rutgers University) sangat tepat menyebut terorisme itu just another war.

Mari kita telaah lebih mendalam. Mitologi Afrika mengenal 6 dewa perang, Mesir 14, Cina 6 (utama) dan ratusan dewa perang lainnya, Greek 25, Roma 9 perang, Hindu 30, Jepang 8, dan Semitik 7. Selain itu, susah menyebut perangperang lebih besar yang hadir atas nama hegemoni dalam sejarah tidak terkait dengan

- Antara 3 sampai 15 juta tercatat tewas karena Thirty Years' War yang dilaksanakan atasnama Holy Roman Empire (1618-1648), dan itu perang atas nama agama (Katholik vs Protestan). Jumlah korban itu mencapai $0.5 \%-2.1 \%$ dari penduduk dunia saat itu.

- Antara 2 hingga 4 juta $(0.4 \%-0.8 \%$ dari penduduk dunia saat itu) telah tewas dalam perang agama antara Katholik dan Protestan di Perancis (1562-1598).

- Serbuan Kristen terhadap Islam dalam perang Salib menewaskan 1 hingga 3 juta jiwa (1095-1291) yang kurang lebih setara dengan $0.3 \%-2.3 \%$ dari penduduk dunia saat itu. 
- Antara 1 hingga 2 juta tewas dalam Perang Sipil Sudan II (1983-2005). Ini perang agama antara Kristen.

- Catatan sejarah dunia juga menyebut antara 130 ribu hingga 250 ribu tewas dalam perang Sipil Libanon yang terjadi antara tahun 1975 hingga 1990. Sunni, Syiah, Jahudi, Druze dan Kristen terlibat di dalamnya.

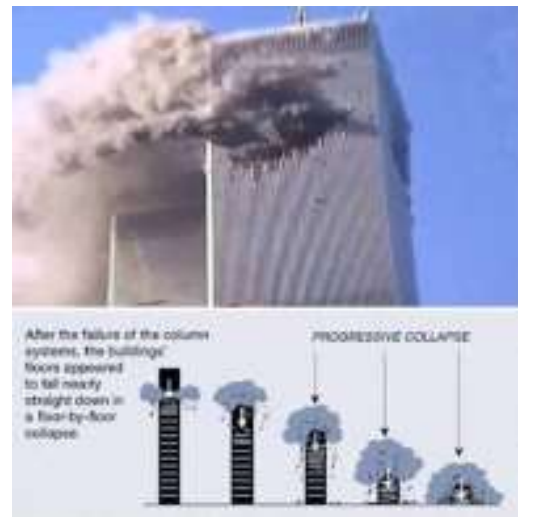

War on terrorism tercatat kian gencar pasca serangan 911 dan sasarannya lebih kepada dunia Islam. Padahal dari 38 video beredar tentang kejadian ini terbukti bahwa kebohongan (hoax) telah dipakai sebagai senjata.

Tak mungkin pesawat terbang dengan bahan utama aluminium bisa menembus konstruksi baja gedung WTC. Tidak mungkin ketinggian gedung yang mesti

dilewati sebelum menabrak WTC dapat memperkenankan sebuah pesawat terbang menembus WTC sebelum merobohkan gedung yang menghadang pada jarak yang lebih dekat.

Tetapi ini sudah menjadi opini dunia dan setiap hari memperburuk citra dan posisi Islam dalam pergaulan internasional.

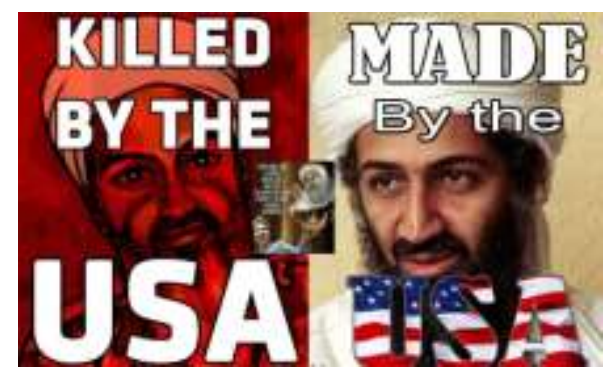

\section{II.TEROR DI INDONESIA}

Amat perlu mengenali pola insiden teror yang pernah terjadi di Indonesia. Data untuk itu kini cukup mudah untuk diakses dari berbagai sumber.

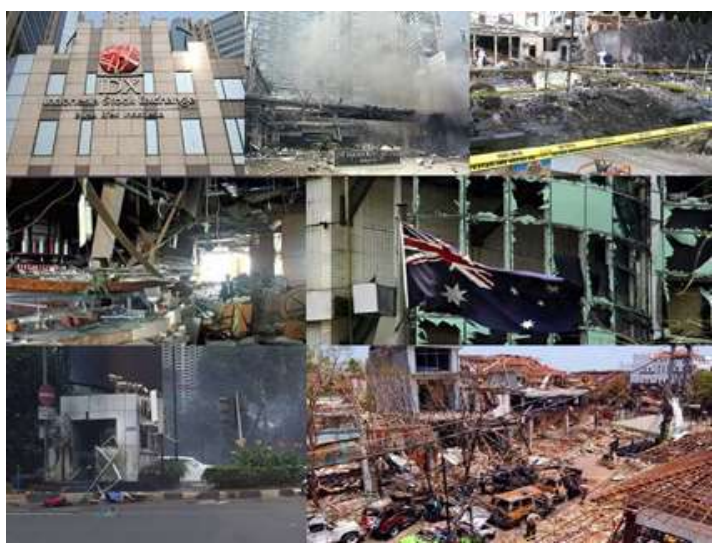

Beberapa ledakan bom yang terjadi di Indonesia sejak tahun 2000 dinyatakan cukup mengguncang dan menjadi perhatian dunia. Pertama, Bom Bursa Efek Jakarta yang trejadi tanggal 13 September 2000 persis satu hari sebelum pembukaan Olimpiade Musim Panas. Kedua, Bom Bali I tanggal 12 Oktober 2002 yang memantik reaksi keras dari banyak negara. Tiga tempat berbeda di Bali menjadi sasaran, yaitu Paddy's Club, Sari Club (SC) di Jalan Legian, Kuta dan di dekat Kantor Konsulat Amerika Serikat.

Ketiga, Bom JW Marriot tanggal 5 Agustus 2003. Bom bunuh diri ini menewaskan 150 orang. Keempat, Bom Kuningan tanggal 9 September 2004 yang ditujukan 
kepada Kantor Kedutaan Besar Australia. Selain membuat beberapa orang meninggal, peristiwa ledakan ini juga membuat bangunan di sekitarnya rusak parah.

Kelima, bom Bali II tanggal 1 Oktober 2005 yang menewaskan sedikitnya 23 orang dan melukasi 196 orang lainnya. Ledakan bom bunuh diri ini juga dilakukan di 3 tempat yang berbeda dengan tipe bom yang berbeda pula: 2 tempat di Kuta dan 1 tempat di kawan Jimbaran, Bali. Keenam, bom Mega Kuningan tanggal 17 Juli 2009 yang menewaskan sedikitnya 9 orang dan melukai 50 orang lainnya. Ketujuh, bom Sarinah tanggal 14 Januari 2016 yang terjadi di sekitar Jalan MH Thamrin, Jakarta. Selain ledakan, terjadi pula baku tembak antara para pelaku dan pihak kepolisian. Sedikitnya 7 orang tewas akibat aksi teror bom tersebut. Di antaranya adalah seorang polisi lalu lintas dan seorang warga Belanda.

Meski terasa sangat tidak adil, umumnya Indonesia mencatat sejarah teror sejak zaman Orde Baru. Padahal apa yang dilakukan terhadap para pejuang dan komunitas-komunitas nasionalis yang menentang kekuasaan kolonial yang bahkan berkategori genosida tak dianggap sebagai teror. Namun di bawah ini diberikan catatan yang umumnya sudah diketahui oleh publik, yakni:

- 1957: Teror bom pertama setelah Indonesia merdeka yang dinyatakan bersasaran Presiden Soekarno yang sedang berkunjung ke sekolah Perguruan Cikini, Jakarta Pusat.

- 1976: Teror bom terjadi di Masjid Nurul Iman di Padang, Sumatera Barat, diledakkan orang tidak dikenal.

- 1978: Masjid Istiqlal, Jakarta, diteror bom, dan belum diketahui pelaku dan motifnya hingga kini.

- 4 Oktober 1984: Bank BCA di Pecenongan, Jakarta Pusat, diledakkan. Aksi ini dikaitkan dengan kelompok yang diberinama Petisi 50.

- 1985: Bus Pemudi Express diledakkan di daerah Banyuwangi, Jawa Timur, dan pada tahun yang sama sejumlah stupa di Candi Borobudur, Jawa Tengah, berantakan dibom.

- 1986: Brigade Anti Imperialisme dari Jepang beraksi dengan sasaran Wisma Metropolitan dan Hotel Presiden (sekarang Hotel Nikko) yang adalah milik pemerintah yang dibangun dengan pampasan perang dari Jepang.

- 1991: Gerilyawan Fretilin Kay Ralla Xanana Gusmao meledakkan bom di Demak, Jawa Tengah.

- 1998: Bulan Januari 1998 bom meledak di sebuah rumah susun di daerah Senen, Jakarta. Pada waktu yang tak berjauhan juga terjadi pemboman tempat parkir kendaraan di Atrium Plaza di Jakarta Pusat.

- 1999: Pusat perbelanjaan Ramayana di Jalan Agus Salim, Jakarta Pusat, diledakkan dengan pelakunya yang sama dengan peledakan Atrium Plaza, pusat perbelanjaan Senen, Jakarta Pusat, tahun 1998. Pada tahun yang sama pusat perbelanjaan Plaza Hayam Wuruk di Jakarta Barat, diledakkan.

- 2000: Saat malam Natal sejumlah gereja di Jakarta, Bekasi, Sukabumi, Bandung, Mojokerto, Mataram, Pematang Siantar, Medan, Batam, dan Pekanbaru, diledakkan.

- 1 Agustus 2000: Bom meledak di kediaman Duta Besar Filipina untuk Indonesia, di Jalan Imam Bonjol, Jakarta Pusat.

- Juli 2002: Bom meledak di Graha Mall Cijantung, Jakarta, dekat komplek Kopassus TNI AD.

- 12 Oktober 2002: Bom meledak di Paddy's Cafe dan Sari Club, dua restoran di Jalan Legian, Kuta, Denpasar, Bali. 
- 5 Agusutus 2003: Bom meledak di Hotel JW Marriot, Jakarta. Korban tewas 14, dan luka-luka 156.

- 10 September 2006: Bom meledak di Kedutaan Besar Australia, Jakarta. Jumlah korban sekitar 6 sampai 9 orang.

- 1 Oktober 2005: Bom meledak di Kuta Bali yang kemudian lebih dikenal sebagai tragedi Bom Bali II.

- 17 Juli 2009: Bom meledak di Hotel JW Marriot dan Ritz Carlton.

- April 2015: Permukiman padat penduduk di kawasan Tanah Abang, Jakarta Pusat, dibom.

- Juli 2015: Bom meledak di Mall Alam Sutera, Tangerang, Banten.

- 28 Oktober 2015: Bom meledak di Mall Alam Sutera.

- November 2015: Bom meledak di Jalan Raden Inten, Duren Sawit, Jakarta Timur.

\section{PENDEKATAN HUKUM DAN PERUNDANG-UNDANGAN}

Di tengah persiapan memasuki bulan suci Ramadhan $1394 \mathrm{H}$ kerusuhan terjadi Mako Brimob yang membawa korban manusia dari pihak aparat (Kepolisian) maupun perusuh (napiter). Kemudian terjadi rangkaian teror di berbagai tempat di Indonesia.

Kasad Jenderal Mulyono saat memberikan arahan di hadapan prajurit Batalyon Infanteri (Yonif) 133/Yudha Sakti, Jumat (18/5) menaruh kecurigaan atas adanya pihak asing yang 'bermain' dalam aksi-aksi bom bunuh diri tersebut.

"Bangsa lain sangat iri dengan kekayaan alam dan budaya yang dimiliki Indonesia. Selain keberagaman budaya, mereka juga ingin mendapatkan kekayaan alam Indonesia ini, namun sering dilakukan dengan cara tidak sehat, salah satunya adalah dengan aksi teror bom yang belakangan terus menghantui masyarakat Indonesia".

la melihat, aksi teror bom adalah salah satu cara negara lain untuk memperebutkan kekayaan alam Indonesia selain dengan peredaran narkoba. Namun Mulyono tak

\section{ISISDI INDONESIA}

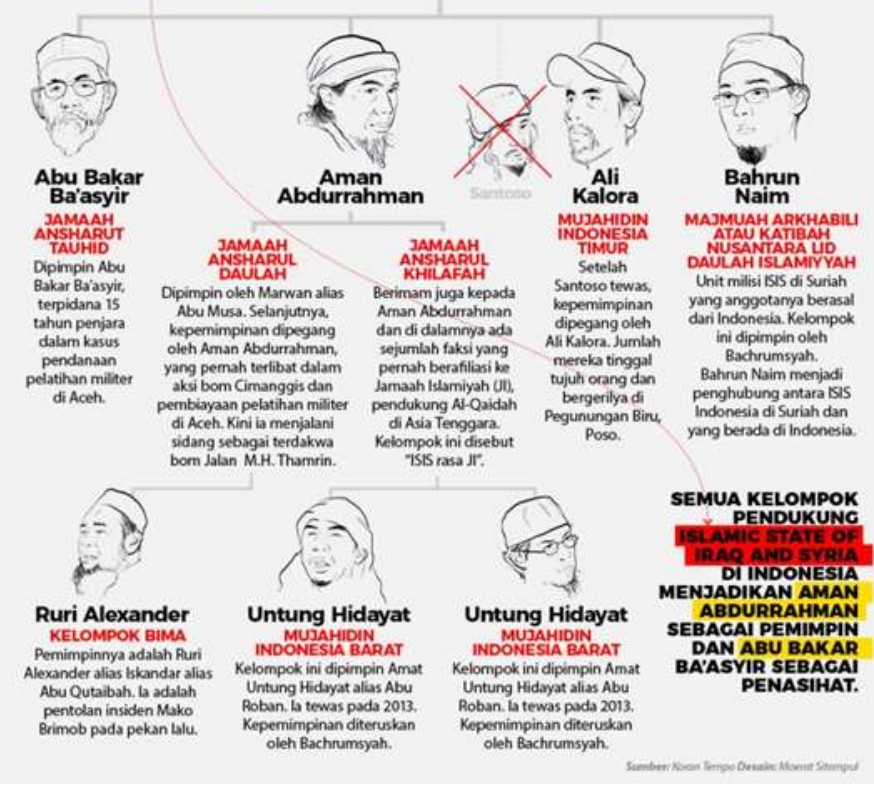
menyebut negara mana berada di belakang aksi teror yang diduga akan memecah belah persatuan Indonesia.

"Saat ini, kita harus bersatu agar tidak mudah dipecah belah oleh negara lain. Aparat keamanan dan pertahanan harus bersatu, jika ada masalah antar-instansi selesaikan dengan baik-baik. Karena hanya dengan demikian, negara lain tidak akan bisa memecah belah bangsa ini. Jika terpecah, negara lain akan datang dengan dalih melakukan aksi perdamaian".

Sejalan dengan itu Prof. Dr H Din Syamsuddin ditegaskan bahwa 
terorisme bukan hanya faktor ideologi (radikal) saja tetapi juga bisa menjadi sangat subur karena faktor-faktor rumit yang berkelindan dalam Poleksosbud. Indonesia yang selama ini memilih hanya percaya dan merasa hanya benar untuk fokus memerangi ideologi saja dan mengabaikan masalah politik, ekonomi, keadilan sosial dan budaya lokal atau politik global, ternyata tak mampu menyintuh akar masalah yang tidak ditemukan sama sekali. Semua kerumitan ini bersifat global, dan jangan nafikan bahwa ini berkaitan dengan operasi intelijen. Intelijen itu bisa asing dan bisa juga lokal.

Para pelaku teror akhirnya menjadi jelas hanya sebagai pion belaka. Ada yang memeliharanya. Mereka diciptakan, untuk pada suatu ketika yang dianggap tepat untuk diperangi sendiri sesuai kepentingan pememeliharaan kepentingan. Auditlah kerugian kemanusiaan dengan perspektif itu. Tentu Anda akan berkata betapa siasianya lilin-lilin yang dibakar oleh mobilisasi-mobilisasi sistematis yang pesan akhirnya pun menyisakan kekeruhan. Ucapan-ucapan gagap yang diviralkan pun, seperti "kami tak takut teror", "Kami mendukung Kepolisian”, akhirnya terasa menjadi upaya menyembunyikan akar masalah sesungguhnya.

Rizal Ramli (2017) dalam dialog dengan sebuah televisi swasta bersama Salim Said dengan tema "Ekonomi Dalam Bingkai Pancasila" begitu tegas mengatakan bahwa radikalisme atau semacamnya tidak perlu dikhawatirkan di sebuah negara yang rakyatnya sejahtera. Inilah agenda yang ditelantarkan dari satu ke lain rezim, dengan catatan kegagapan dalam memilih strategi dan model pembangunan yang terlalu kanan (neoliberalis).

Pasca rangkaian kejadian teror belakangan ini langsung saja masalah Revisi UndangUndang nomor 15 tahun 2003 tentang Pemberantasan Tindak Pidana Terorisme menjadi sorotan. Pembahasannya yang cukup lama tertunda menjadi pusat perhatian penting.

Presiden Joko Widodo sendiri pun berkata: "Saya juga minta ke DPR dan kementerian terkait yang berhubungan dengan revisi UU Tindak Pidana Terorisme, yang sudah kita ajukan pada bulan Februari 2016 yang lalu, sudah dua tahun, untuk segera diselesaikan secepat-cepatnya dalam masa sidang berikut 18 Mei yang akan datang". Joko Widodo menyatakan itu melalui akun Twitter-nya (Tirto.id, 14 Mei 2018).

Saat ini semua pihak berpendapat koor akan perlunya pengesahan Revisi UU Nomor 15 Tahun 2003 yang kelak akan menjadi payung hukum bagi aparat untuk mencegah tindak pidana terorisme, sebagaimana ditegaskan oleh Kapolri Jenderal Dr Muhammad Tito Karnavian pada sebuah acara diskusi teevisi swasta di Jakarta, Selasa pekan lalu.

Secara umum UU No 15 Tahun 2003 itu sifatnya dianggap reaktif belaka, dan bahkan ada yang menyebut lebih terbatas pada petingnya kesegeraan menyelesaikan kasus 
khusus pada teror bom Bali tempohari. Kelemahan UU itu misalnya, bahwa jika pelaku teror belum bertindak, sama sekali tidak bisa ditangkap. Sedangkan pihak berwajib berharap diberi kewenangan melakukan upaya preventif.

\section{SIKAP DAN TINDAKAN}

Masalah regulasi menjadi kewenangan pemerintah pusat (Eksekutif-Legislatif). Sedangkan langkah-langkah untuk mengantisipasi setiap ancaman menjadi tanggung jawab semua warga negara di seluruh NKRI.

Berdasarkan uraian tersebut di atas, Lembaga Hikmah dan Kebijakan Publik PW Muhammadiyah Sumatera Utara menganggap penting untuk menyelenggarakan rangkaian kegiatan bernama "CALANG POTENSI MEMERANGI TEROR" dengan tujuan:

- menyamakan persepsi di antara komponen bangsa di Sumatera Utara;

- menggalang seluruh potensi untuk semakin waspada terhadap kejadian teror khususnya di Sumatera Utara;

- memberi rasa aman bagi semua pihak, tak terkecuali para investor dan dunia usaha;

GALANC POTENSI MEMERANGI TEROR dilaksanakan pada level dan dengan tahapan-tahapan tertentu sebagai berikut:

- pertemuan stakeholder pada level provinsi dengan pelibatan seluruh unsur pemerintahan dan organisasi sosial kemasyarakatan serta wakil dunia usaha dan Konsulat Jenderal Negara sahabat di Medan. Pada pertemuan ini narasumber utama ialah Gubernur, Pangdam I/BB, Kapoldasu dan para pimpinan organisasi kemasyarakatan. Dipandang perlu sebuah dokumen komitmen ditandatangani untuk menjadi konsumsi publik;

- pertemuan-pertemuan serupa pada level Kabupaten/Kota dengan menyederhanakan perwilayahan menjadi 5 (lima) zona:

- Zona I (Medan, Binjai, Langkat, Deliserdang, Langkat, Karo, Dairi dan Pakpak Bharat);

- Zona II (Serdangbedagai, Tebingtinggi, Pematangsiantar, Simalungun, Batubara, Asahan dan Tanjungbalai);

- Zona III (Labuhanbatu Utara, Labuhanbatu dan Labuhanbatu Selatan);

- Zona IV (Padanglawas, Padanglawas Utara, Tapanuli Selatan, Kota Padangsidempuan dan Madina);

- Zona V (Tapanuli Utara, Humbahas, Tobasa, Samosir, Tapanuli Tengah dan Sibolga). 